\title{
Application of statistical experimental methods to optimize medium for exopolymer production by newly isolated Halobacterium sp. SM5
}

\author{
Patcharee Lungmann \\ Department of Industrial Biotechnology \\ Faculty of Agro-Industry \\ Prince of Songkla University \\ Hat Yai, Songkhla 90112 Thailand \\ Tel: 6644611221 \\ Fax: 6644612858 \\ E-mail: plungmann@yahoo.com \\ Wanna Choorit* \\ Biotechnology Program \\ School of Agricultural Technology \\ Walailak University \\ Nakhonsithammarat 80160, Thailand \\ Tel: 66075672355 \\ Fax: 66075672302 \\ E-mail: cwanna@wu.ac.th \\ Poonsuk Prasertsan \\ Department of Industrial Biotechnology \\ Faculty of Agro-Industry \\ Prince of Songkla University \\ Hat Yai, Songkhla 90112 Thailand \\ Tel: 6674286361 \\ Fax: 6674446727 \\ E-mail: poonsuk918@yahoo.com
}

Financial support: This research was supported by a research grant of Prince of Songkla University.

Keywords: exopolymer, halophilic bacteria, medium optimization, mixture design, response surface method.

$\begin{array}{ll}\text { Abbreviations: } & \text { CI: confidence interval } \\ & \text { KS medium: Kamekura and Seno medium } \\ & \text { PHB: Poly- } \beta \text {-hydroxybutyrate } \\ & \text { RSM: response surface methodology }\end{array}$

The study investigated on medium optimization for production of exopolymer by a newly isolated bacterium, Halobacterium sp. SM5, using the mixture design and response surface method. The mixture experiment was designed by setting five parameters at the lowest and highest of concentrations: pseudo components design containing 0.15-0.25 glucose, 0.150.25 yeast extract, $0.35-0.45 \quad \mathrm{MgSO}_{4} \cdot 7 \mathrm{H}_{2} \mathrm{O}, \quad 0.1-0.2$ vitamin casamino acid and $0.02-0.06 \mathrm{KCl}$. The results of the mixture design revealed that the effect of nutrients or elements on the exopolymer produced by the strain SM5 were in the order of $\mathrm{MgSO}_{4} \cdot 7 \mathrm{H}_{2} \mathrm{O}>$ yeast extract > vitamin casamino acid $>\mathrm{KCl}>$ glucose, respectively. The suitable medium recipe for enhancement the exopolymer production was $7.43 \mathrm{~g} / \mathrm{l}$ glucose, $12.38 \mathrm{~g} / \mathrm{l}$ yeast extract, $17.33 \mathrm{~g} / \mathrm{l} \mathrm{MgSO}_{4} \cdot 7 \mathrm{H}_{2} \mathrm{O}, 9.9 \mathrm{~g} / \mathrm{l}$ vitamin casamino acid and $2.48 \mathrm{~g} / \mathrm{l} \mathrm{KCl}$. The exopolymer to be produced by the strain SM5 was $2.25 \mathrm{~g} / \mathrm{l}$, which was higher than that obtained in the original medium (1.3 times). The yield of exopolymer was $2.13 \mathrm{~g} / \mathrm{l}$ to be obtained in medium containing $7.43 \mathrm{~g} / \mathrm{l}$ glucose, $11.37 \mathrm{~g} / \mathrm{l}$ yeast extract, $22.28 \mathrm{~g} / \mathrm{l} \mathrm{MgSO}_{4} \cdot 7 \mathrm{H}_{2} \mathrm{O}, 7.44 \mathrm{~g} / \mathrm{l}$ vitamin casamino acid and $0.99 \mathrm{~g} / \mathrm{l} \mathrm{KCl}$ which was predicted by response surface methodology. However, under an experiment, the yield of exopolymer was $2.08 \pm 0.0020$ g/l.

Prokaryotes have the ability to produce exopolymer in the form of capsule or slime. The exopolymer has the rheological property in aqueous system which enhances the viscosity of the solution making it applicable as thickeners, emulsifiers, and suspending agents in food, pharmaceutical

*Corresponding author 
and petroleum industries (Llamas et al. 1999; Sleytr et al. 2003; Kumar et al. 2004). Most commercialized exopolymers are derived from eubacteria like, Xanthomonas campestris (xanthan) (Becker et al. 1998; Vendruscolo et al. 2005), Sphingomonas paucimobilis (gellan) (Jin et al. 2003; Lee et al. 2004), Agrobacterium (curdlan) (Saudagar and Singhal, 2004), Aureobasidium pullulans and Kluyveromyces fragilis (pullulan) (Seo et al. 2004), Acetobacter xylinum (cellulose) (Sutherland, 2001; Czaja et al. 2006) and Zymomonas mobilis (levan) (Bekers et al. 2005).

Halophilic bacteria have been reported to produce industrially interesting products such as bacteriorhodopsin, enzyme, bioplastic and exopolymer (Aguilar et al. 1998; Ventosa et al. 1998; Hezayen et al. 2000; Margesin and Schinner, 2001; Birbir and Sesal, 2003). The exopolymer from an extremely halophilic bacterium, Halomonas eruihalina exhibits viscous properties at low $\mathrm{pH}$ values (Bejar et al. 1998). This property would make it valuable for use in the food industry as an additive in salad sauces or citric desserts, where the $\mathrm{pH}$ is usually acidic. Moreover, viscosity of polysaccharides from halophilic bacteria (Bacillus species) displays pseudoplastic behaviour, which is resistant to shear, salt, thermal degradation, and develops a higher viscosity at dilute concentrations (Ventosa et al. 1998; Margesin and Schinner, 2001). These findings on the properties of exopolymer from the halophilic bacteria suggest that production of exopolymers from diverse bacteria would offer a good prospect for industrial application.

In the screening process for the exopolymer, one isolated halophilic bacterial strain, SM5, was found to produce an exopolymer containing protein as a major component with sugar, uronic acid, and sulphate as minor components. In addition, the exopolymer has a high molecular weight, acidic charge, is water-soluble, exhibits high viscosity and is able to form a gel in acid solution. These results suggest that the bacterium produce a glycoprotein exopolymer which has potential medical and nanotechnological applications (Margesin and Schinner, 2001). In addition, sulphate polymer can also be applied in the pharmaceutical industry as an antiviral agent (Ying et al. 2002), antitumoral agent (Geresh et al. 2002) and anticoagulant agent (Nardi et al. 2004).

In general, media are traditionally optimized by the one-ata-time strategy, i.e., varying one factor while keeping all others constant. Although this strategy is simple and easy to apply without the need for statistical analysis, it involves a relatively large number of experiments and the interaction among factors is often ignored. In contrast, mixture design, full factorial design, and fractional factorial design are more efficient approaches that can deal with a large number of variables simultaneously. Moreover, the interaction among different variables can be estimated. To date, these techniques have been used by many researchers to optimize medium components, such as astaxanthin production from
Phaffia rhodozyma (Ramirez et al. 2001), xylanase from halophilic eubacterium SX15 (Wejse et al. 2003), $\beta$ glucanase production from Bacillus subtilis ZJE-1A5 (Tang et al. 2004), clavulanic acid from Streptomyces clavuligerus (Wang et al. 2005), micrococcin GO5 from Micrococcus sp. GO5 (Kim et al. 2006) and xyloketal A from Xylaria sp. 2508 (Xiaobo et al. 2006).

The objective of this work was to apply a mixture design followed by a response surface methodology to investigate and optimize a medium (five variables such as glucose, yeast extract, $\mathrm{MgSO}_{4} \cdot 7 \mathrm{H}_{2} \mathrm{O}$, vitamin casamino and $\mathrm{KCl}$ ) which might positively affect exopolymer production by the newly isolated Halobacterium sp. SM5.

\section{MATERIALS AND METHODS}

\section{Isolation of halophilic bacterium}

Thai traditional fermented fish (Pla-ra), purchased from the market in Songkhla Province, Thailand, was used as a source for the isolation of a halophilic bacterium. A loopful of sample was streaked onto a KS medium (Kamekura and Seno, 1990). The plate was incubated at $37^{\circ} \mathrm{C}$ for 15 days. A viscous-looking colony was picked up and purified by streaking method. The purification process was repeated several times until a pure culture was obtained.

\section{Medium and cultivation of the halophilic bacterium}

In order to prepare a starter culture, a loopful of the isolated strain, designated as SM5, was transferred into $100 \mathrm{ml}$ of modified KS medium in a $250 \mathrm{ml}$ Erlenmyer flask and incubated in an orbital shaker (New Brunswick G25-KLG) at $200 \mathrm{rpm}$ at $37^{\circ} \mathrm{C}$ until its growth reached the early stationary phase. To prepare the inoculum for exopolymer production, $10 \%$ of the starter culture adjusted to a cell concentration (optical density, $\mathrm{OD}_{660}$ ) of 0.5 was transferred into the fresh medium. Generally, nutrient compositions used for the starter culture preparation and for adjusting the concentration of inoculum were varied according to the media to be investigated (Table 1). The culture was taken every $24 \mathrm{hrs}$ for growth and exopolymer measurements. Growth was determined in terms of turbidity by using a spectrophotometer (Hitachi U-2000) at a wavelength of $660 \mathrm{~nm}$. Composition of the modified KS medium was the same as the KS medium with the exception of the addition of $10 \mathrm{~g} / \mathrm{l}$ glucose.

\section{Preparation of exopolymer}

After removing the cell pellet by centrifugation, $5 \mathrm{ml}$ of the supernatant was precipitated with 3 volumes of cold ethanol. The precipitated exopolymer was then re-dissolved in distilled water and dialysed against distilled water overnight using the membrane with 10,000 daltons molecular cut-off. The lyophilized exopolymer obtained was measured and calculated as $\mathrm{g} / \mathrm{l}$. 


\section{Medium optimization using mixture design}

Firstly, 5 components, $10 \mathrm{~g} / 1$ glucose, $10 \mathrm{~g} / 1$ yeast extract, $20 \mathrm{~g} / 1 \mathrm{MgSO}_{4} \cdot 7 \mathrm{H}_{2} \mathrm{O}, 7.5 \mathrm{~g} / \mathrm{l}$ vitamin casamino acid and 2 $\mathrm{g} / \mathrm{l} \mathrm{KCl}$, of the modified $\mathrm{KS}$ medium were selected. The total weight of these 5 components in distilled water was calculated to be $4.95 \%(\mathrm{w} / \mathrm{v})$. Then each component was calculated into percent of the total $(=4.95)$ and displayed in decimal fraction. The lowest and highest volume fractions were designed from the calculated results \pm 0.05 (Table 2). Finally, the data obtained from Table 2 were entered into the JMP version 3.2.6 program (software of SAS Institute Inc) followed by selecting an extreme vertices design. The pseudo components of five factors $(\mathrm{A}=$ glucose, $\mathrm{B}=$ yeast extract, $\mathrm{C}=\mathrm{MgSO}_{4} \cdot 7 \mathrm{H}_{2} \mathrm{O}, \mathrm{D}=$ vitamin casamino acid and $\mathrm{E}=\mathrm{KCl}$ ) in the ranges from the lowest to highest levels of their volume fractions were obtained. These 30 pseudo components were converted to actual corresponding weights by using percent solids as shown in Table 1. After that the observed responses for the 30 pseudo components and traditional components were determined.

First model. The linear model for predicting the optimal point was expressed according to the equation:

$$
Y=\beta_{1} A+\beta_{2} B+\beta_{3} C+\beta_{4} D+\beta_{5} E
$$

Where $\mathrm{Y}$ is the predicted response; $\beta_{1}, \beta_{2}, \beta_{3}, \beta_{4}$ and $\beta_{5}$ are the coefficients estimate, and $\mathrm{A}, \mathrm{B}, \mathrm{C}, \mathrm{D}$ and $\mathrm{E}$ are the studied factors (Hu, 1999).

\section{Statistical analysis}

A test for significant sequential models was performed by employing a statistical methodology called an analysis of variance (ANOVA). The response surface methodology (RSM), was also utilized to predict the optimization of medium for exopolymer production. The DESIGNEXPERT 6.0.1 software was used for the RSM.

\section{RESULTS AND DISCUSSION}

\section{Mixture design}

The production of growth-associated exopolymer from the newly isolated Halobacterium sp. SM5 reached maximum $(1.73 \mathrm{~g} / \mathrm{l})$ after 6 days cultivation in the modified $\mathrm{KS}$ medium (pH 7.0) on a shaker $(200 \mathrm{rpm})$ at $37^{\circ} \mathrm{C}$ (Figure 1). The exopolymer obtained from this strain was nearly 6 times higher than that $(0.3 \mathrm{~g} / \mathrm{l})$ produced by Haloferax mediterranei strain R4 (ATCC 33500) grown in a medium containing a mixture of $25 \%$ salts with $1 \%$ glucose (Parolis et al. 1996). The yield was similar to the exopolymer from Halomonas eruihalina (1.6 g/l) cultivated in MY medium supplemented with sea-salt solution to reach a $7.5 \%(\mathrm{w} / \mathrm{v})$ salt concentration (Bejar et al. 1998).

For optimization of this product, the mixture design experiment with the observed responses of the 30 formulations and the original point were determined. The results showed that the exopolymer yields varied within the range of 1.22-2.25 g/l (Table 1). The exopolymer production was highest in media formula No. 23 which contained $7.43 \mathrm{~g} / \mathrm{l}$ glucose, $12.38 \mathrm{~g} / \mathrm{l}$ yeast extract, $17.33 \mathrm{~g} / \mathrm{l}$ $\mathrm{MgSO}_{4} \cdot 7 \mathrm{H}_{2} \mathrm{O}, 9.9 \mathrm{~g} / \mathrm{l}$ vitamin casamino acid and $2.48 \mathrm{~g} / \mathrm{l}$ $\mathrm{KCl}$ while the lowest exopolymer concentration was obtained in formula No. 4 which contained $11.88 \mathrm{~g} / 1$ glucose, $12.38 \mathrm{~g} / 1$ yeast extract, $17.33 \mathrm{~g} / 1 \mathrm{MgSO}_{4} \cdot 7 \mathrm{H}_{2} \mathrm{O}$, $4.95 \mathrm{~g} / \mathrm{l}$ vitamin casamino acid and $2.97 \mathrm{~g} / 1 \mathrm{KCl}$.

To select an appropriate type of model for the response exopolymer production, the DESIGN-EXPERT software was applied. Sequential F-tests are performed, starting with a linear model and adding terms (quadratic, and higher if appropriate). The F-statistic is calculated for each type of model, and the highest order model with significant terms normally would be chosen. An ANOVA table for sequential model sum of squares is shown in Table 3 . In this table, the linear model is the highest order model with significance terms (Prob $>F$ is less than 0.05); therefore the linear terms should be included in the model whereas the quadratic model is the Prob $>F$ of 0.9977 exceeds 0.05 , the quadratic terms should not be included in the model. The linear model was high $F$ value (34.67) as significant (Prob $>F$ is less than 0.0001). Therefore, the linear model was appropriated for the response exopolymer production. This was confirmed by the adjusted R-Squared value $(81.78 \%)$ (data not shown). The R-Squared value indicates that five components altogether would explain about $81 \%$ of the variability in the responses whereas about $19 \%$ of the variability in the responses remains unexplained.

Due to the results of the ANOVA analysis, multiple linear regression analysis was employed to determine the predicted response (exopolymer yield) function. Table 4 shows the results of the analysis of the pseudo components experiment as follows: The regression coefficient estimates of glucose, yeast extract, $\mathrm{MgSO}_{4} \cdot 7 \mathrm{H}_{2} \mathrm{O}$, vitamin casamino acid and $\mathrm{KCl}$ were $0.66,2.11,2.18,2.10$, and 1.45 , respectively. The last two columns of the tables indicated the $95 \%$ confidence interval (CI) for the coefficients. These interval ranges mean the true coefficients could be found in the corresponding estimated intervals 95 times out of 100 times of the experiments.

Thus, the estimated regression equation for the pseudo components is:

$$
\mathrm{Y}=0.66 \mathrm{~A}+2.11 \mathrm{~B}+2.18 \mathrm{C}+2.10 \mathrm{D}+1.45 \mathrm{E}
$$

Finally, the DESIGN-EXPERT program gave the output of the final equation in terms of actual components as follow:

$$
Y=-0.069 A+0.067 B+0.063 C+0.066 D+0.011 F
$$

Where the variables take their coded values, represents exopolymer yield (Y) as a function of glucose (A), yeast 
extract (B), $\mathrm{MgSO}_{4} \cdot 7 \mathrm{H}_{2} \mathrm{O}(\mathrm{C})$, vitamin casamino acid (D) and $\mathrm{KCl}(\mathrm{E})$ concentrations.

In the above equation, glucose has a negative effect on the exopolymer production. This indicates that for every one unit increase in glucose, the exopolymer production will decrease by 0.069 units when other components hold constant.

In addition to Table 4, the results from DESIGN-EXPERT program revealed the adjusted components affected to the exopolymer production (Table 5). Obviously, the Prob $>|t|$ was less than 0.01 for glucose, yeast extract, $\mathrm{MgSO}_{4} \cdot 7 \mathrm{H}_{2} \mathrm{O}$, and vitamin casamino acid, it can also be concluded that these four components contribute to the model. It can also conclude that $\mathrm{KCl}$ did not effect to the exopolymer production as can be seen that it's Prob $>|t|$ is as big as 0.3392 .

\section{Model diagnostics}

Residual analysis was used to examine the adequacy of the model as shown in Figure 2. The normal probability plot in Figure 2a, which is used to check the violation of normality assumption, revealed no serious violation (i.e. the points line approximately along a straight line). Figure $2 b, 2 c$ and $2 \mathrm{~d}$ could be used to detect the constant variance assumption. However, Figure $2 \mathrm{c}$ was more appropriated for the current model diagnostics since the experiment involved in the time sequence in which the data were collected (Montgomery et al. 1992). Since the plot in Figure $2 \mathrm{c}$ showed a horizontal band, there was no obvious model of defects.

\section{Triaxial diagrams}

Triaxial diagrams are a common mean to express compositions usually employed for obtaining certain exopolymer product. It is a graphic representation of combinations of raw materials, rather than a predictive illustration of product. These numerical results are represented in a triangular graph (Figure 3) which shows the level curves of exopolymer yield as a function of the compositions, obtained from a linear regression. From DX6 program analysis, the 5 experimental points were performed to better identify region of interest and predict higher exopolymer yield (Table 6). It means that the combination of the three components $\left(\mathrm{MgSO}_{4} \cdot 7 \mathrm{H}_{2} \mathrm{O}\right.$, yeast extract, and vitamin casamino acid) lead to higher yield. A high synergetic effect can be observed in the central area of this graph. This time, a constrained area inside the previous experimental region was analysed. Another series of real compositions were used, namely the lowest component for glucose and $\mathrm{KCl}, 10.01-11.37(\mathrm{~g} / \mathrm{l})$ for yeast extract, 21.17$22.28(\mathrm{~g} / \mathrm{l})$ for $\mathrm{MgSO}_{4} \cdot 7 \mathrm{H}_{2} \mathrm{O}, 7.44-9.90(\mathrm{~g} / \mathrm{l})$ for vitamin casamino acid correspond, approximately, to the maximum of yield. In this case, the predicted maximum value of exopolymer was around $2.13 \mathrm{~g} / \mathrm{l}$ whereas the actual experiment gave the maximum exopolymer yield of about
$2.08 \pm 0.0020 \mathrm{~g} / \mathrm{l}$ from using the medium containing 7.43 $\mathrm{g} / 1$ glucose, $11.37 \mathrm{~g} / 1$ yeast extract, $22.28 \mathrm{~g} / 1 \mathrm{MgSO}_{4} \cdot 7 \mathrm{H}_{2} \mathrm{O}$, $7.44 \mathrm{~g} / \mathrm{l}$ vitamin casamino acid and $0.99 \mathrm{~g} / 1 \mathrm{KCl}$ (Table 6).

Medium composition can significantly affect the production of exopolymer as observed in this study. Xu et al. (2003) used one-factor-at-a time and orthogonal matrix method for optimizing exo-biopolymer produced by Paecilomyces tenuipes $\mathrm{C} 240$. The exopolymer $1.89 \mathrm{~g} / \mathrm{l}$ was produced in the medium containing $3 \mathrm{~g} / 1$ glucose, $0.4 \mathrm{~g} / 1 \mathrm{KNO}_{3}, 0.1 \mathrm{~g} / 1$ $\mathrm{K}_{2} \mathrm{HPO}_{4}$, and $0.1 \mathrm{~g} / 1 \mathrm{MgSO}_{4} \cdot 7 \mathrm{H}_{2} \mathrm{O}$ in shake flask. Shih et al. (2002) used the central composite design for optimizing poly ( $\gamma$-glutamic acid) $(\gamma$-PGA) produced by Bacillus licheniformis. The model predicted the highest $\gamma$-PGA of $19.80 \pm 1.59 \mathrm{~g} / 1$ obtained in the medium containing 24.50 $\mathrm{g} / 1$ citric acid, $57.30 \mathrm{~g} / 1$ glutamic acid and $157.11 \mathrm{~g} / 1$ glycerol. Grothe et al. (1999) used central composite experimental design for optimizing poly ( $\beta$ - hydroxybutyric acid) (PHB) produced by Alcaligenes latus. The poly PHB $2.97 \mathrm{~g} / 1$ was produced in the optimized medium containing $20 \mathrm{~g} / 1$ sucrose and $1.5 \mathrm{~g} / \mathrm{l}$ ammonium sulfate, which was 1.8 fold greater than the yield in the screening experiment. Rao et al. (2000) used $2^{5-1}$ fractional central composition design for optimizing hirudin produced by Saccharomyces cerivisiae. The hirudin $65.3 \mathrm{mg} / \mathrm{l}$ was produced in the optimized medium containing $16 \mathrm{~g} / 1$ yeast extract, which was $35 \%$ higher than the unoptimized medium. Hsieh et al. (2005) used RSM for optimizing polysaccharide produced by Cordyceps sinensis. The maximum polysaccharide of $3.17 \mathrm{~g} / \mathrm{l}$ was predicted from the regression model of RSM in the medium containing $6.17 \%$ sucrose, $0.53 \%$ corn steep powder, $0.5 \%\left(\mathrm{NH}_{4}\right)_{2} \mathrm{HPO}_{4}$ and $0.15 \% \mathrm{KH}_{2} \mathrm{PO}_{4}$. When applying this optimal medium, the maximum polysaccharide production was 3.05 and $3.21 \mathrm{~g} / \mathrm{l}$ in a shake flask and a 2-1 jar fermentor, respectively. Cui et al. (2006) used a three-level Box-Behnken factorial design for optimizing mycelial biomass and exopolymer produced by Grifola frondosa GF 9801. The model estimated that, a maximal yield of mycelia biomass $(17.61 \mathrm{~g} / \mathrm{l})$ could be obtained when the concentrations of glucose, $\mathrm{KH}_{2} \mathrm{PO}_{4}$, peptone were set at $45.2 \mathrm{~g} / 1,2.97 \mathrm{~g} / 1,6.58 \mathrm{~g} / 1$, respectively; while a maximal exopolymer yield $(1.326 \mathrm{~g} / \mathrm{l})$ could be achieved when setting concentrations of glucose, $\mathrm{KH}_{2} \mathrm{PO}_{4}$, peptone at $58.6 \mathrm{~g} / \mathrm{l}, 4.06 \mathrm{~g} / \mathrm{l}$ and $3.79 \mathrm{~g} / 1$, respectively.

From the survey of literature, it can be seen that the application of statistical experimental design techniques in fermentation process development can result in improved product yield, reduced process variability, closer confirmation of the output response (product yield or productivity) in relation to nominal and target requirements, and reduced development time overall costs.

\section{CONCLUDING REMARKS}

The data obtained from our experiments demonstrated the strategies for enhancing exopolymer and analysing the factors that affected exopolymer production by Halobacterium sp. SM5. The medium No. 23 formulated 
by mixture design was superior to other media in terms of original compositions for enhancing exopolymer production. The results of linear model for mixture design experiments showed that the yeast extract, $\mathrm{MgSO}_{4} \cdot 7 \mathrm{H}_{2} \mathrm{O}$ and vitamin casamino acid gave positive effect while glucose gave negative effect for exopolymer production. The $\mathrm{KCl}$ exhibited no effect on exopolymer production. Therefore, the yeast extract, $\mathrm{MgSO}_{4} \cdot 7 \mathrm{H}_{2} \mathrm{O}$ and vitamin casamino acid were chosen for the response surface design to enhance yield of exopolymer.

\section{REFERENCES}

AGUILAR, Apolonio; INGEMANSSON, Torbjörn and MAGNIEN, Etienne. Extremophile microorganisms as cell factories: support from the European Union. Extremophiles, August 1998, vol. 2, no. 3, p. 367-373.

BECKER, A.; KATZEN, F.; PUHLER, A. and IELPI, L. Xanthan gum biosynthesis and application: a biochemical/genetic perspective. Applied Microbiology and Biotechnology, August 1998, vol. 50, no. 2, p. 145-152.

BEJAR, Victoria; LLAMAS, Immaculada; CALVO, Concepción and QUESADA, Emilia. Characterization of exopolysaccharides produced by 19 halophilic strains of the species Halomonas eurihalina. Journal of Biotechnology, April 1998, vol. 61, no. 2, p. 135-141.

BEKERS, M.; UPITE, D.; KAMINSKA, E.; LAUKEVICS, J.; GRUBE, M.; VIGANTS, A. and LINDE, R. Stability of levan produced by Zymomonas mobilis. Process Biochemistry, April 2005, vol. 40, no. 5, p. 1535-1539.

BIRBIR, Meral and SESAL, Cenk. Extremely Halophilic bacterial communities in Sereflikoçhisar Salt Lake in Turkey. Turkish Journal of Biology, February 2003, vol. 27, no. 1, p. 7-22.

CUI, F.J.; LI, Y.; XU, Z.H.; XU, H.Y.; SUN, K. and TAO, W.Y. Optimization of medium composition for production of mycelial biomass and exo-polymer by Grifola frondosa GF9801 using response surface methodology. Bioresource Technology, July 2006, vol. 97, no. 10, p. 1209-1216.

CZAJA, Wojciech; KRYSTYNOWICZ, Alina; BIELECKI, Stanislaw and BROWN, R. Malcolm. Microbial cellulose the natural power the heal wounds. Biomaterials, January 2006, vol. 27, no. 2, p. 145-151.

GERESH, Shimona; MAMONTOV, Anna and WEINSTEIN, Jacob. Sulfation of extracellular polysaccharides of red microalgae: preparation, characterization and properties. Journal of Biochemical and Biophysical Methods, January 2002, vol. 50, no. 2-3, p. 179-187.

GROTHE, Enrico; MOO-YOUNG, Murray and CHISTI, Yusuf. Fermentation optimization for the production of poly ( $\beta$-hydroxybutyric acid) microbial thermoplastic.
Enzyme and Microbial Technology, July 1999, vol. 25, no. 1-2, p. 132-141.

HEZAYEN, F.F.; REHM, B.H.A.; EBERHARDT, R. and STEINBUCHEL, A. Polymer production by two newly isolated extremely halophilic archaea: application of a novel corrosion-resistant bioreactor. Applied Microbiology and Biotechnology, September 2000, vol. 54, no. 3, p. 319325 .

HSIEH, Chienyan; TSAI, Ming-Jin; HSU, Tai-Hao; CHANG, Der-Ming and LO, Chaur-Tsuen. Medium optimization for polysaccharide production of Cordyceps sinensis. Applied Biochemistry and Biotechnology, February 2005, vol. 120, no. 2, p. 145-158.

HU, Ruguo. Food Product Design: A computer-Aided Statistical Approach. Technomic Publishing CO. Ltd. Pennsylvania, 1999, 240 p. ISBN 1-56-676743-1.

JIN, Hyuck; LEE, Nam-Kyu; SHIN, Myung-Kyo; KIM, Sung-Koo; KAPLAN, David L. and LEE, Jin-Woo. Production of gellan gum by Sphingomonas paucimobilis NK2000 with soybean pomace. Biochemical Engineering Journal, December 2003, vol. 16, no. 3, p. 357-360.

KAMEKURA, M. and SENO, Y. A halophilic extracellular protease from a halophilic archaebacterium strain $172 \mathrm{P} 1$. Biochemistry and Cell Biology, January 1990, vol. 68, no. 1, p. 352-359.

KIM, Mi-Hee; KONG, Yoon-Jung; BAEK, Hong and HYUN, Hyung-Hwan. Optimization of culture conditions and medium composition for the production of micrococcin GO5 by Micrococcus sp. GO5. Journal of Biotechnology, January 2006 , vol. 121 , no. 1, p. 54-61.

KUMAR, C. Ganesh; JOO, Han-Seung; CHOI, Jang-Won; KOO, Yoon-Moo and CHANG, Chung-Soon. Purification and characterization of an extracellular polysaccharide from haloalkalophillic Bacillus sp. I-450. Enzyme and Microbial Technology, June 2004, vol. 34, no. 7, p. 673-681.

LEE, Kwang Yeon; SHIM, Jaeyong and LEE, Hyeon Gyu. Mechanical properties of gellan and gelatin composite films. Carbohydrate Polymers, June 2004, vol. 56, no. 2, p. 251-254.

LLAMAS, Inmaculada; BEJAR, Victoria; ARGANDONA, Montserrat; QUESADA, Emilia and DEL MORAL, Ana. Chemical mutagenesis of Halomonas eurihalina and selection of exopolysaccharide-deficient variants. Biotechnology Letters, May 1999, vol. 21, no. 5, p. 367370.

MARGESIN, Rosa and SCHINNER, Franz. Potential of halotolerant and halophilic microorganisms for biotechnology. Extremophiles, April 2001, vol. 5, no. 2, p. 73-83. 
MONTGOMERY, Douglas C.; VINING, G. Geoffrey and PECK, Elizabeth A. Introduction to linear regression analysis. John and Wiley and Sons INC, New York, 1992, 612 p. ISBN 0-47-175495-1.

NARDI, J.V.; ACCHAR, W. and HOTZA, D. Enhancing the properties of ceramic products through mixture design and response surface analysis. Journal of the European Ceramic Society, January 2004, vol. 24, no. 2, p. 375-379.

PAROLIS, Haralambos; PAROLIS, Lesley A.S.; BOAN, Isabel F.; RODRIGUEZ-VALERA, Francisco; WIDMALM, Göran; MANCA, M. Cristina; JANSSON, Per-Erik and SUTHERLAND, Ian W. The structure of the exopolysaccharide produced by the halophilic archaeon Haloferax mediterranei strain R1 (ATCC 33500). Carbohydrate Research, December 1996, vol. 295, p. 147156.

RAMIREZ, Jesús; GUTIERREZ, Humberto and GSCHAEDLER, Anne. Optimization of astaxanthin production by Phaffia rhodozyma through factorial designs and response surface methodology. Journal of Biotechnology, July 2001, vol. 88, no. 3, p. 259-268.

RAO, K.J.; KIM, C.-H. and RHEE, S.-K. Statistical optimization of medium for the production of recombinant hirudin from Saccharomyces cerevisiae using response surface methodology. Process Biochemistry, February 2000, vol. 35, no. 7, p. 639-647.

SAUDAGAR, Parag S. and SINGHAL, Rekha S. Curdlan as a support matrix for immobilization of enzyme. Carbohydrate Polymers, July 2004, vol. 56, no. 4, p. 483488.

SEO, Hyung-Pil; SON, Chang-Woo; CHUNG, Chung-Han; JUNG, Dae-Il; KIM, Sung-Koo; GROSS, Richard A.; KAPLAN, David L. and LEE, Jin-Woo. Production of high molecular weight pullulan by Aureobasidium pullulans HP2001 with soybean pomace as a nitrogen source. Bioresource Technology, December 2004, vol. 95, no. 3, p. 293-299.

SHIH, I.L.; VAN, Y.T. and CHANG, Y.N. Application of statistical experimental methods to optimize production of poly ( $\gamma$-glutamic acid) by Bacillus licheniformis CCRC 12826. Enzyme and Microbial Technology, August 2002, vol. 31, no. 3, p. 213-220.

SLEYTR, Uwe B.; GYORVARY, Erika and PUM, Dietmar. Crystallization of S-layer protein lattices on surfaces and interfaces. Progress in Organic Coatings, September 2003, vol. 47, no. 3-4, p. 279-287.

SUTHERLAND, Ian W. Microbial polysaccharides from gram-negative bacteria. International Dairy Journal, 2001, vol. 11, no. 9, p. 663-674.
TANG, Xing-Jun; HE, Guo-Qing; CHEN, Qi-He; ZHANG, Xiu-Yan and ALI, Mokhtar A.M. Medium optimization for the production of thermal stable $\beta$-glucanase by Bacillus subtilis ZJF-1A5 using response surface methodology. Bioresource Technology, June 2004, vol. 93, no. 2, p. 175181.

VENDRUSCOLO, C.W.; ANDREAZZA, I.F.; GANTER, J.L.M.S.; FERRERO, C. and BRESOLIN, T.M.B. Xanthan and galactomannan (from M. scabrella) matrix tablets for oral controlled delivery of theophylline. International Journal of Pharmaceutics, May 2005, vol. 296, no. 1-2, p. $1-11$.

VENTOSA, Antonio; NIETO, Joaquín J. and OREN, Aharon. Biology of moderately halophilic aerobic bacteria. Microbiology and Molecular Biology Reviews, June 1998, vol. 62 , no. 2 , p. 504-544.

WANG, Yong-Hua; YANG, Bo; REN, Jie; DONG, MeiLing; LIANG, Dong and XU, An-Long. Optimization of medium composition for the production of clavulanic acid by Streptomyces clavuligerus. Process Biochemistry, March 2005, vol. 40, no. 3-4, p. 1161-1166.

WEJSE, Peter Langborg; INGVORSEN, Kjeld and MORTENSEN, Kim Kusk. Xylanase production by a novel halophilic bacterium increased 20 -fold by response surface methodology. Enzyme and Microbial Technology, May 2003, vol. 32, no. 6, p. 721-727.

XIAOBO, Zeng; HAIYING, Wang; LINYU, He; YONGCHENG, Lin and ZHONGTAO, Li. Medium optimization of carbon and nitrogen sources for the production of eucalyptene A and xyloketal A from Xylaria sp. 2508 using response surface methodology. Process Biochemistry, February 2006, vol. 41, no. 2, p. 293-298.

XU, Chun-Ping; KIM, Sang-Woo; HWANG, Hye-Jin; CHOI, Jang-Won and YUN, Jong-Won. Optimization of submerged culture conditions for mycelial growth and exobiopolymer production by Paecilomyces tenuipes C240. Process Biochemistry, February 2003, vol. 38, no. 7, p. 1025-1030.

YING, C.; VAN PELT, J.F.; VAN LOMMEL, A.; VAN RANST, M.; LEYSSEN, P.; DE CLERCQ, E. and NEYTS, J. Sulphated and sulphonated polymers inhibit the initial interaction of hepatitis B virus with hepatocytes. Antiviral Chemical and Chemotherapy, May 2002, vol. 13, no. 3, p. 157-164. 


\section{APPENDIX \\ TABLES}

Table 1. Design matrix for mixture design and results of response exopolymer production.

\begin{tabular}{|c|c|c|c|c|c|c|c|c|c|c|c|c|c|c|c|}
\hline Exp & Std & Block & $A^{a}$ & $\mathrm{~B}^{\mathrm{a}}$ & $C^{a}$ & $D^{a}$ & $\mathrm{E}^{\mathrm{a}}$ & $A^{b}$ & $B^{b}$ & $c^{b}$ & $D^{b}$ & $E^{b}$ & $\begin{array}{l}\text { Exopo } \\
\text { lymer } \\
(g / l)\end{array}$ & $\begin{array}{l}\text { Predicted } \\
\text { exopolymer } \\
\text { (g/l) }\end{array}$ & Residual \\
\hline Orig. & 23 & 1 & 0.20 & 0.20 & 0.40 & 0.15 & 0.04 & 10.0 & 10.0 & 20.0 & 7.5 & 2.0 & 1.73 & 1.74 & $-7.6 \mathrm{E}-003$ \\
\hline 1 & 9 & 1 & 0.18 & 0.25 & 0.45 & 0.10 & 0.02 & 8.91 & 12.38 & 22.28 & 4.95 & 0.99 & 1.77 & 1.95 & -0.18 \\
\hline 2 & 27 & 1 & 0.25 & 0.18 & 0.45 & 0.10 & 0.02 & 12.38 & 8.91 & 22.28 & 4.95 & 0.99 & 1.60 & 1.51 & 0.090 \\
\hline 3 & 26 & 1 & 0.25 & 0.25 & 0.38 & 0.10 & 0.02 & 12.38 & 12.38 & 18.81 & 4.95 & 0.99 & 1.50 & 1.49 & 0.010 \\
\hline 4 & 11 & 1 & 0.24 & 0.25 & 0.35 & 0.10 & 0.06 & 11.88 & 12.38 & 17.33 & 4.95 & 2.97 & 1.22 & 1.43 & -0.21 \\
\hline 5 & 1 & 1 & 0.25 & 0.24 & 0.35 & 0.10 & 0.06 & 12.38 & 11.88 & 17.33 & 4.95 & 2.97 & 1.28 & 1.37 & -0.087 \\
\hline 6 & 21 & 1 & 0.25 & 0.25 & 0.35 & 0.10 & 0.05 & 12.38 & 12.38 & 17.33 & 4.95 & 2.48 & 1.37 & 1.40 & -0.025 \\
\hline 7 & 10 & 1 & 0.25 & 0.25 & 0.35 & 0.13 & 0.02 & 12.38 & 12.38 & 17.33 & 6.44 & 0.99 & 1.58 & 1.48 & 0.10 \\
\hline 8 & 30 & 1 & 0.24 & 0.15 & 0.45 & 0.10 & 0.06 & 11.88 & 7.43 & 22.28 & 4.95 & 2.97 & 1.50 & 1.46 & 0.041 \\
\hline 9 & 6 & 1 & 0.25 & 0.15 & 0.44 & 0.10 & 0.06 & 12.38 & 7.43 & 21.78 & 4.95 & 2.97 & 1.44 & 1.39 & 0.047 \\
\hline 10 & 28 & 1 & 0.25 & 0.15 & 0.45 & 0.10 & 0.05 & 12.38 & 7.43 & 22.28 & 4.95 & 2.48 & 1.53 & 1.42 & 0.11 \\
\hline 11 & 19 & 1 & 0.25 & 0.15 & 0.45 & 0.13 & 0.02 & 12.38 & 7.43 & 22.28 & 6.44 & 0.99 & 1.35 & 1.51 & -0.16 \\
\hline 12 & 5 & 1 & 0.25 & 0.15 & 0.35 & 0.19 & 0.06 & 12.38 & 7.43 & 17.33 & 9.41 & 2.97 & 1.47 & 1.36 & 0.11 \\
\hline 13 & 24 & 1 & 0.25 & 0.18 & 0.35 & 0.20 & 0.02 & 12.38 & 8.91 & 17.33 & 9.90 & 0.99 & 1.45 & 1.48 & -0.026 \\
\hline 14 & 14 & 1 & 0.25 & 0.15 & 0.38 & 0.20 & 0.02 & 12.38 & 7.43 & 18.81 & 9.90 & 0.99 & 1.44 & 1.49 & -0.045 \\
\hline 15 & 2 & 1 & 0.25 & 0.15 & 0.35 & 0.20 & 0.05 & 12.38 & 7.43 & 17.33 & 9.90 & 2.48 & 1.34 & 1.39 & -0.051 \\
\hline 16 & 15 & 1 & 0.15 & 0.24 & 0.45 & 0.10 & 0.06 & 7.43 & 11.88 & 22.28 & 4.95 & 2.97 & 2.01 & 2.02 & -0.014 \\
\hline 17 & 3 & 1 & 0.15 & 0.25 & 0.44 & 0.10 & 0.06 & 7.43 & 12.38 & 21.78 & 4.95 & 2.97 & 2.14 & 2.02 & 0.12 \\
\hline 18 & 29 & 1 & 0.15 & 0.25 & 0.45 & 0.10 & 0.05 & 7.43 & 12.38 & 22.28 & 4.95 & 2.48 & 2.15 & 2.05 & 0.097 \\
\hline 19 & 20 & 1 & 0.15 & 0.25 & 0.45 & 0.13 & 0.02 & 7.43 & 12.38 & 22.28 & 6.44 & 0.99 & 2.24 & 2.14 & 0.10 \\
\hline 20 & 22 & 1 & 0.15 & 0.25 & 0.35 & 0.19 & 0.06 & 7.43 & 12.38 & 17.33 & 9.41 & 2.97 & 1.89 & 1.99 & -0.10 \\
\hline 21 & 18 & 1 & 0.18 & 0.25 & 0.35 & 0.20 & 0.02 & 8.91 & 12.38 & 17.33 & 9.90 & 0.99 & 1.93 & 1.92 & 0.014 \\
\hline 22 & 25 & 1 & 0.15 & 0.25 & 0.38 & 0.20 & 0.02 & 7.43 & 12.38 & 18.81 & 9.90 & 0.99 & 2.01 & 2.11 & -0.10 \\
\hline 23 & 12 & 1 & 0.15 & 0.25 & 0.35 & 0.20 & 0.05 & 7.43 & 12.38 & 17.33 & 9.90 & 2.48 & 2.25 & 2.02 & 0.23 \\
\hline 24 & 13 & 1 & 0.15 & 0.15 & 0.45 & 0.19 & 0.06 & 7.43 & 7.43 & 22.28 & 9.41 & 2.97 & 1.80 & 2.02 & -0.22 \\
\hline 25 & 7 & 1 & 0.18 & 0.15 & 0.45 & 0.20 & 0.02 & 8.91 & 7.43 & 22.28 & 9.90 & 0.99 & 2.15 & 1.95 & 0.20 \\
\hline
\end{tabular}




\begin{tabular}{|l|l|l|l|l|l|l|l|l|l|l|l|l|l|l|l|}
\hline 26 & 17 & 1 & 0.15 & 0.18 & 0.45 & 0.20 & 0.02 & 7.43 & 8.91 & 22.28 & 9.90 & 0.99 & 2.12 & 2.13 & -0.014 \\
\hline 27 & 31 & 1 & 0.15 & 0.15 & 0.45 & 0.20 & 0.05 & 7.43 & 7.43 & 22.28 & 9.90 & 2.48 & 1.73 & 2.05 & -0.32 \\
\hline 28 & 16 & 1 & 0.24 & 0.15 & 0.35 & 0.20 & 0.06 & 11.88 & 7.43 & 17.33 & 9.90 & 2.97 & 1.51 & 1.43 & 0.085 \\
\hline 29 & 8 & 1 & 0.15 & 0.24 & 0.35 & 0.20 & 0.06 & 7.43 & 11.88 & 17.33 & 9.90 & 2.97 & 2.02 & 1.99 & 0.029 \\
\hline 30 & 4 & 1 & 0.15 & 0.15 & 0.44 & 0.20 & 0.06 & 7.43 & 7.43 & 21.78 & 9.90 & 2.97 & 2.19 & 2.02 & 0.18 \\
\hline
\end{tabular}

${ }^{a}$ Pseudo components (designed by using JMP program).

${ }^{\mathrm{b}}$ Factor unit $(\mathrm{g} / \mathrm{l}): \mathrm{A}=$ glucose; $\mathrm{B}=$ yeast extract; $\mathrm{C}=\mathrm{MgSO}_{4} \cdot 7 \mathrm{H}_{2} \mathrm{O}$; $\mathrm{D}$ : vitamin cassamino acid; $\mathrm{E}=\mathrm{KCl}$; Exp $=\operatorname{experiment} ; \mathrm{Std}=$ standard order; Orig. = original experiment.

Table 2. Mixture components and volume fraction ranges.

\begin{tabular}{|l|c|c|}
\hline \multicolumn{1}{|c|}{ Component } & Lowest volume fraction & Highest volume fraction \\
\hline $\mathrm{A}=$ glucose & 0.15 & 0.25 \\
\hline $\mathrm{B}=$ yeast extract & 0.15 & 0.25 \\
\hline $\mathrm{C}=\mathrm{MgSO}_{4} \cdot 7 \mathrm{H}_{2} \mathrm{O}$ & 0.35 & 0.45 \\
\hline $\mathrm{D}=$ vitamin casamino acid & 0.10 & 0.20 \\
\hline $\mathrm{E}=\mathrm{KCl}$ & 0.02 & 0.06 \\
\hline
\end{tabular}

Table 3. ANOVA sequential models sum of squares.

\begin{tabular}{|l|c|c|c|c|c|}
\hline \multicolumn{1}{|c|}{ Source } & Sum of Square & DF & Mean Square & F value & Prob $>\boldsymbol{F}$ \\
\hline Mean & 93.07 & 1 & 93.07 & & \\
\hline Linear & 2.67 & 4 & 0.67 & 34.67 & $<0.0001$ \\
\hline Quadratic & 0.043 & 10 & $4.323 \mathrm{E}-003$ & 0.15 & 0.9977 \\
\hline Special Cubic (aliased) & 0.18 & 5 & 0.035 & 1.37 & 0.3063 \\
\hline Cubic (aliased) & 0.16 & 6 & 0.027 & 1.15 & 0.4482 \\
\hline Residual & 0.12 & 5 & 0.024 & & \\
\hline Total & 96.24 & 31 & 3.10 & & \\
\hline
\end{tabular}

$\mathrm{DF}=$ degree of freedom. 
Table 4. ANOVA and regression of linear model for exopolymer.

\begin{tabular}{|l|c|c|c|c|c|}
\hline \multicolumn{1}{|c|}{ Variable component } & $\begin{array}{c}\text { Coefficient } \\
\text { estimate }\end{array}$ & $\begin{array}{c}\text { Degree of } \\
\text { freedom }\end{array}$ & S.E & 95\% Cl low & 95\% Cl high \\
\hline Regression analysis & & & & & \\
\hline $\mathrm{A}=$ glucose & 0.66 & 1 & 0.10 & 0.46 & 0.87 \\
\hline $\mathrm{B}=$ yeast extract & 2.11 & 1 & 0.10 & 1.90 & 2.32 \\
\hline $\mathrm{C}=\mathrm{MgSO}_{4} \cdot 7 \mathrm{H}_{2} \mathrm{O}$ & 2.18 & 1 & 0.10 & 1.97 & 2.38 \\
\hline $\mathrm{D}=$ vitamin casamino acid & 2.10 & 1 & 0.10 & 1.89 & 2.31 \\
\hline $\mathrm{E}=\mathrm{KCl}$ & 1.45 & 1 & 0.29 & 0.86 & 2.05 \\
\hline
\end{tabular}

S.E = Standard Error; $\mathrm{Cl}=$ Confidence interval

Table 5. Statistical data of each parameter effected on exopolymer produced by the strain SM5.

\begin{tabular}{|l|c|c|c|c|c|}
\hline \multicolumn{1}{|c|}{ Variable component } & $\begin{array}{c}\text { Adjusted Degree of Adjusted } \\
\text { effect }\end{array}$ & $\begin{array}{c}\text { Approximate } \\
\text { freedom } \\
\text { S.E } \\
\mathbf{t} \text { for } \mathbf{H}_{0} \\
\text { effect = 0 }\end{array}$ & Prob > | t | \\
\hline $\mathrm{A}=$ glucose & -0.56 & 1 & 0.062 & -7.62 & $<0.0001$ \\
\hline $\mathrm{B}=$ yeast extract & 0.22 & 1 & 0.062 & 3.09 & 0.0048 \\
\hline $\mathrm{C}=\mathrm{MgSO}_{4} \cdot 7 \mathrm{H}_{2} \mathrm{O}$ & 0.26 & 1 & 0.062 & 2.82 & 0.0091 \\
\hline $\mathrm{D}=$ vitamin casamino acid & 0.22 & 1 & 0.062 & 3.52 & 0.0016 \\
\hline $\mathrm{E}=\mathrm{KCl}$ & -0.054 & 1 & 0.055 & -0.97 & 0.3392 \\
\hline
\end{tabular}

S.E $=$ Standard Error

Table 6. Mixtures used in the experiment approach.

\begin{tabular}{|c|c|c|c|c|c|c|}
\hline Point & $\begin{array}{c}\text { Glucose } \\
(\mathbf{g} / \mathbf{l})\end{array}$ & $\begin{array}{c}\text { Yeast extract } \\
\text { (g/l) }\end{array}$ & $\mathrm{MgSO}_{4} \cdot 7 \mathrm{H}_{2} \mathrm{O}(\mathrm{g} / \mathrm{l})$ & $\begin{array}{l}\text { Vitamin } \\
\text { casamino } \\
\text { acid (g/l) }\end{array}$ & $\begin{array}{l}\mathrm{KCl} \\
(\mathrm{g} / \mathrm{l})\end{array}$ & $\begin{array}{l}\text { Exopolymer } \\
(g / l) \pm \text { S.D }\end{array}$ \\
\hline 1 & 7.43 & 10.01 & 21.17 & 9.90 & 0.99 & $1.98 \pm 0.0020$ \\
\hline 2 & 7.43 & 11.37 & 22.28 & 7.44 & 0.99 & $2.08 \pm 0.0020$ \\
\hline 3 & 7.43 & 10.17 & 21.87 & 9.04 & 0.99 & $2.01 \pm 0.0031$ \\
\hline 4 & 7.43 & 11.30 & 22.28 & 7.51 & 0.99 & $2.03 \pm 0.0023$ \\
\hline 5 & 7.43 & 11.30 & 21.81 & 7.97 & 0.99 & $2.01 \pm 0.0031$ \\
\hline
\end{tabular}




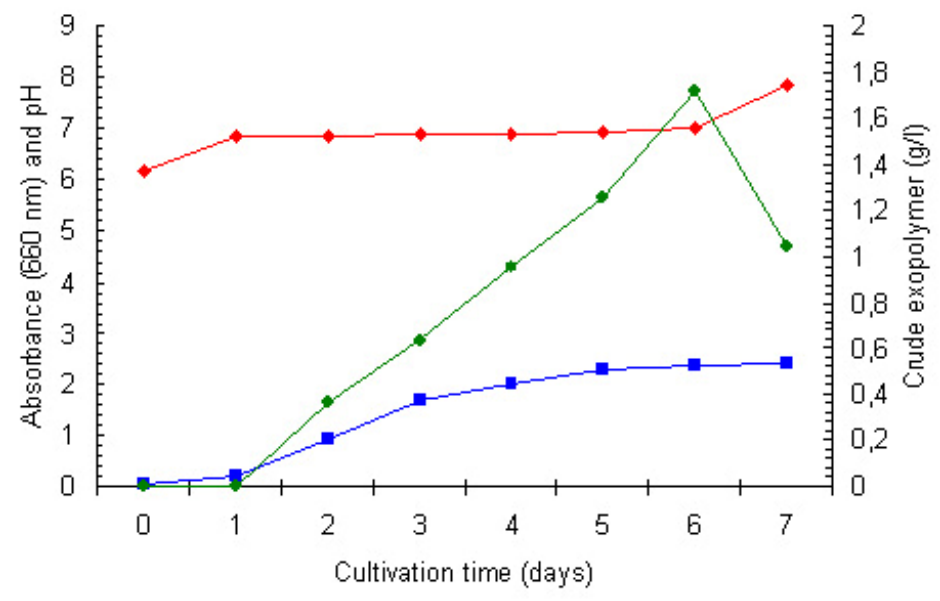

$\rightarrow-$ Absorbance $(660 \mathrm{~nm}) \multimap \mathrm{pH} \longrightarrow$ Crude exopolymer $(\mathrm{g} / \mathrm{l})$

Figure 1. Time course on exopolymer production and growth of the newly isolated Halobacterium sp. SM5.
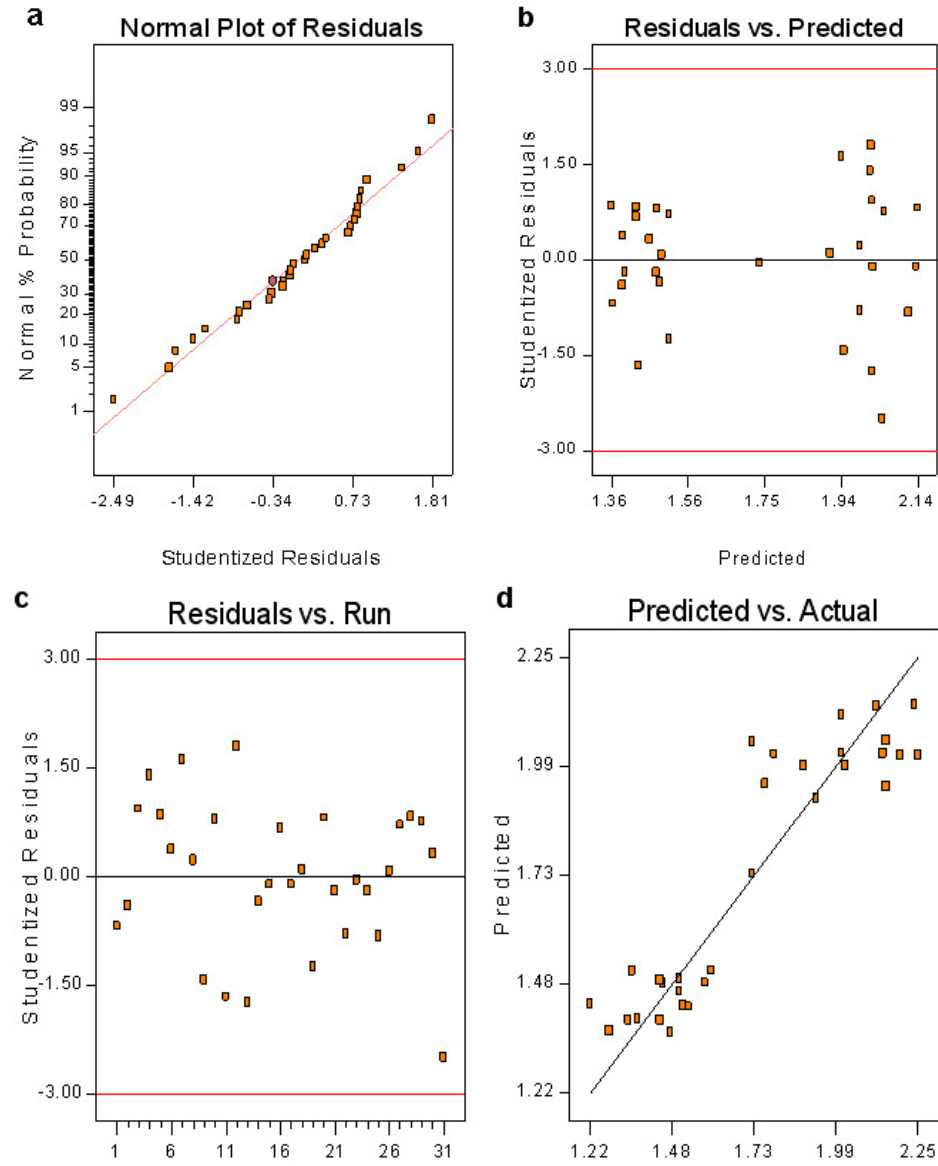

d Predicted vs. Actual

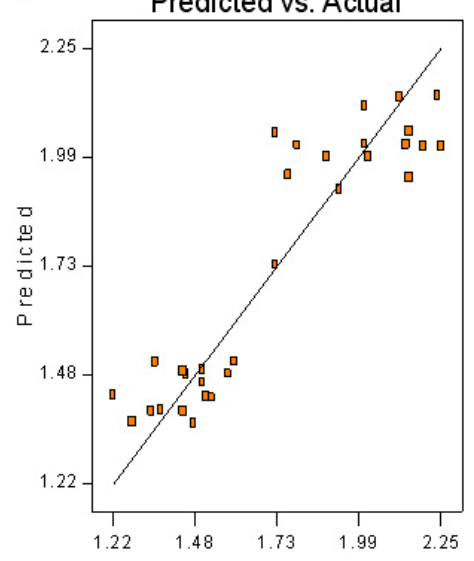

Run Number

Actual

Figure 2. Residual diagnostics of mixture model for exopolymer production.

(a) Normal probability versus residuals.

(b) Residuals versus predicted.

(c) Residuals versus run order.

(d) Predicted versus actual. 
DESIGN-EXPERT PIot

$$
\begin{aligned}
& \text { exopolymer } \\
& \text { - Design Points }
\end{aligned}
$$

$X 1=B$ : Yeast Extract

$X 2=\mathrm{C}: \mathrm{MgSO} 4$

$\times 3=D$ : CassAmino

Actual Components

A: Glucose $=7.43$

$\mathrm{E}: \mathrm{KCl}=0.99$

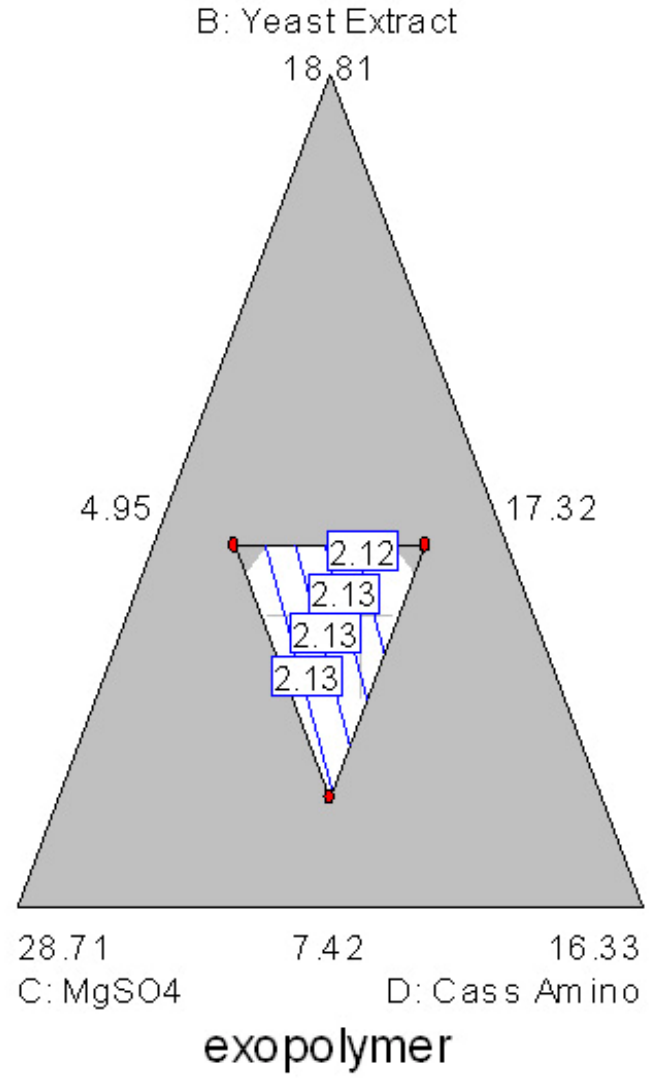

Figure 3. Response surface of the expected exopolymer yield for the experimental approach. 